\title{
High-Mobility Group Box 1 Contributes to Lethality of Endotoxemia in Heme Oxygenase-1-Deficient Mice
}

\author{
Rina Takamiya ${ }^{1,4 *}$, Chi-Chih Hung1, Sean R. Hall' ${ }^{1}$ Koichi Fukunaga ${ }^{1,6}$, Takashi Nagaishi ${ }^{3,5}$, Toshitaka Maeno1, \\ Caroline Owen 1, Alvaro A. Macias ${ }^{1}$, Laura E. Fredenburgh', Akitoshi Ishizaka6 , Richard S. Blumberg ${ }^{3}$, \\ Rebecca M. Baron', and Mark A. Perrella1,2 \\ ${ }^{1}$ Division of Pulmonary and Critical Care Medicine, Department of Medicine, ${ }^{2}$ Newborn Medicine, and ${ }^{3}$ Division of Gastroenterology, Department \\ of Medicine, Brigham and Women's Hospital and Harvard Medical School, Boston, Massachusetts; ${ }^{4}$ Department of Biochemistry and Integrative \\ Medical Biology, School of Medicine, Keio University, Tokyo, Japan; ${ }^{5}$ Department of Gastroenterology and Hepatology, Tokyo Medical and Dental \\ University, Tokyo, Japan; and ${ }^{6}$ Division of Pulmonary Medicine, School of Medicine, Keio University, Tokyo, Japan
}

\begin{abstract}
High-mobility group box 1 (HMGB1) is a nuclear protein that has been found to be a critical mediator of lethality in endotoxemia and sepsis. During the systemic inflammatory response, circulating levels of HMGB1 are increased, but in a delayed fashion compared with early inflammatory mediators. To counteract the inflammatory response of endotoxemia, a secondary anti-inflammatory response ensues in an attempt to prevent inflammation-induced tissue injury. One such cytoprotective gene that is induced during endotoxemia is heme oxygenase (HO)-1. HO-1, and its products of heme metabolism, possess anti-inflammatory and antioxidant properties to counter the damaging effects of endotoxemia. In the present study, we wanted to determine whether tissue and circulating levels of HMGB1 are increased further in the absence of HO-1 during endotoxemia, and whether this increase may contribute to the pathobiology of endotoxemia. Lung inflammation, HMGB1 protein levels, and expression of $\mathrm{HMGB} 1$ in inflammatory cells were increased in $\mathrm{HO}-1^{-/-}$mice compared with $\mathrm{HO}-1^{+/+}$mice. After the administration of LPS, tissue levels of HMGB1 were not increased further in $\mathrm{HO}-1^{-/-}$mice; however, circulating levels of $\mathrm{HMGB} 1$ were higher when compared with $\mathrm{HO}-1^{+/+}$mice. $\mathrm{HO}-1^{-/-}$mice treated with a carbon monoxide-releasing molecule or biliverdin showed a reduction in plasma HMGB1, which was associated with a marked improvement in survival. $\mathrm{HO}-1^{-/-}$mice given HMGB1-neutralizing antibody showed improvement in survival compared with control antibody. These data suggest that exaggerated circulating levels of HMGB1 contribute to endotoxin-induced mortality in the absence of HO-1.
\end{abstract}

Keywords: endotoxemia; heme oxygenase-1; inflammation; highmobility group box 1 ; oxidative stress

Heme oxygenase (HO) enzymes are important cytoprotective enzymes that are critical for physiologic homeostasis (1-4). The inducible isoform, $\mathrm{HO}-1$, responds rapidly to diverse physical and chemical stimuli by transcriptional activation and increased expression (5); however, HO-1 is also expressed under basal

(Received in original form August 24, 2008 and in final form November 22, 2008)

* Present affiliation: Department of Disease Glycomics, The Institute of Scientific and Industrial Research, Osaka University, Osaka, Japan

This work was supported by National Institutes of Health grants HL60788 and GM053249 (M.A.P.), DK51362 (R.S.B.), and a Grant-in-Aid for Young Investigators (20790575) and Keio University research grants for life science and medicine (R.T.)

Correspondence and requests for reprints should be addressed to Mark A. Perrella, M.D., Division of Pulmonary and Critical Care Medicine, Brigham and Women's Hospital, 75 Francis St., Boston, MA 02115. E-mail: mperrella@ rics.bwh.harvard.edu

This article has an online supplement, which is accessible from this issue's table of contents at www.atsjournals.org

Am J Respir Cell Mol Biol Vol 41. pp 129-135, 2009

Originally Published in Press as DOI: 10.1165/rcmb.2008-03310C on December 18, 2008

Internet address: www.atsjournals.org

\section{CLINICAL RELEVANCE}

These results may have implications for patients at increased risk for inflammation and oxidative stress. A deficiency of heme oxygenase (HO)-1 leads to increased lung inflammation and enhanced release of HMGB1 during endotoxemia. These data provide further insight into the pathophysiology of endotoxemia, and additional support for the therapeutic potential of HO-1-derived heme metabolites in inflammatory disease processes.

conditions. HO enzymes catalyze the first and rate-limiting step in the oxidative degradation of heme, resulting in the production of carbon monoxide (CO), biliverdin, and ferrous iron $(2,3,6)$. Biliverdin is converted to bilirubin, a potent endogenous antioxidant $(7,8)$, and recently it has been recognized that biliverdin also has anti-inflammatory properties (9). CO also has numerous biological functions, with anti-inflammatory properties (1-4) being vital for its biological actions. Thus, these two products of heme catabolism have overlapping properties that may have benefit to counteract a systemic inflammatory stimulus. Using HO-1-deficient mice, it has been shown that the HO-1 enzyme is important for defending the body against inflammatory and oxidant-induced cellular and tissue injury (1013). Previous work in our laboratory has shown, in a mouse model of endotoxemia, that an absence of HO-1 leads to increased oxidative stress, end-organ injury, and death (13).

The anti-inflammatory properties of $\mathrm{HO}-1$, and the products of heme catabolism, have been shown to involve inhibition of early proinflammatory cytokines (e.g., TNF- $\alpha$ and IL-1 $\beta$ ) and induction of the anti-inflammatory cytokine, IL-10 (14). The balance of pro- and anti-inflammatory mediators characterizes the pathophysiologic response to endotoxemia, and, if an exaggerated proinflammatory response ensues, this will lead to enhanced oxidative stress and mortality. It has been suggested that the absence of HO-1 correlates with a shift toward a proinflammatory environment (15). Proinflammatory cytokines, such as TNF- $\alpha$ and IL- $1 \beta$, mediate the early inflammatory response to lethal endotoxemia and bacteremia (16). Recently, it has become apparent that another important mediator of endotoxemia and sepsis is high-mobility group box (HMGB) 1 (17-19). HMGB1 is a nuclear protein that is released during a systemic inflammatory response, resulting in increased circulating levels, but in a delayed fashion compared with TNF- $\alpha$ or IL-1 $\beta$ (17-19). Cells critical for the production and active release of HMGB1 during an inflammatory response are monocytes and macrophages (17). Studies using neutralizing antibodies to HMGB1 have shown that increased circulating levels of HMGB1 contribute to the late lethality of endotoxemia and sepsis (17-20). 
Acute lung injury (ALI) is a consequence of a variety of insults, including inflammation, which may have subsequent systemic manifestations (21). When administered to the lungs, HMGB1 has been shown to be a mediator of ALI, resulting in inflammatory cell accumulation, pulmonary edema, and production of proinflammatory mediators (22). Moreover, the ability of HMGB1 to inhibit the phagocytosis of apoptotic neutrophils, and thus neutrophil clearance, may also contribute to its inflammatory response (23). Administration of neutralizing antibodies to HMGB1 results in decreased inflammatory cell migration and decreased edema in lungs after exposure to endotoxin (22). HMGB1 has also been shown to participate in the ALI associated with hemorrhage (24), another insult associated with a cascade of inflammatory mediators leading to injury. Thus, HMGB1 is a known mediator of lung injury associated with a systemic inflammatory response. Recent studies suggest that the inflammatory activity of HMGB1 is weak by itself (25); however, HMGB1 enhances this activity by binding with proinflammatory mediators, such as IL-1 $\beta$ (26), and with bacteria-derived substances, such as lipids $(23,25)$, to increase its inflammatory response.

Because HO-1 is an endogenous cytoprotective enzyme that is involved in the pathophysiologic response to endotoxemia and $\operatorname{ALI}(13,27,28)$, we sought to determine whether tissue and circulating levels of HMGB1 are altered in the absence of HO-1 during endotoxemia in vivo, and whether an increase in HMGB1 may contribute to the lethality of endotoxemia in HO-1-deficient mice. We also sought to ascertain whether the downstream products of heme catabolism mediated by HO-1-namely, CO and biliverdin-could suppress the circulating levels of HMGB1 during endotoxemia and improve survival in HO-1-deficient mice.

\section{MATERIALS AND METHODS}

\section{Reagents and Murine Endotoxemia Model}

Pseudomonas aeruginosa LPS (serotype 10; Sigma, St. Louis, MO) was used for the endotoxemia studies. Wild-type $(+/+)$ or homozygousnull $(-/-)$ female mice for targeted disruption of HO-1 (12) on a BALB/c genetic background were studied at 8-10 weeks of age. Mice were treated with an intraperitoneal injection of LPS at the indicated doses and times. The vehicle used to dissolve the LPS, $0.9 \%$ $\mathrm{NaCl}$, was used in the control mice. CO-releasing molecules (RM) are transition metal carbonyls, which liberate $\mathrm{CO}$ to elicit direct biological activities (29). The CO-RM used in our experiments was tricarbonyldichlororuthenium (II) dimer $\left(\left[\mathrm{Ru}(\mathrm{CO})_{3} \mathrm{Cl}_{2}\right]_{2}\right.$; Sigma) dissolved in a $12.5 \%$ DMSO solution (which was used as the vehicle for control experiments). Biliverdin (Frontier Science, Logan, UT) was dissolved in $0.1 \mathrm{~N} \mathrm{NaOH}$ and then adjusted to a $\mathrm{pH}$ of 7.4 with $\mathrm{HCl}$ (vehicle for control experiments was prepared exactly as the solution used to dissolve biliverdin). Both CO-RM and biliverdin were administered intraperitoneally at the indicated doses and times.

\section{Immunohistochemical Analyses}

Tissue was fixed in methyl Carnoy's solution and then in 70\% ethanol before processing and embedding in paraffin. Immunohistochemistry was performed as previously described $(30,31)$, and sections were stained with antibodies against HMGB1 (1:500; Shino-Test Corp., Sagamihara, Kanagawa, Japan) and CD45 (leukocyte common antigen, 1:1,000; BD Biosciences, San Jose, CA). To assess inflammatory cell accumulation and HMGB1 localization in the lung, the areas staining positive for CD45 and HMGB1 were measured by colorimetric analysis (30).

\section{Preparation of Single-Cell Suspensions and Immunofluorescent Labeling for FACS Analyses}

To isolate lung leukocytes, mice were killed and the lung vasculature was flushed with $20 \mathrm{ml}$ of PBS by inserting a catheter into the right ventricle of the heart. Whole mouse lungs were minced and digested in serum-free RPMI 1,640 medium supplemented with $1 \mathrm{mg} / \mathrm{ml}$ collagenase type IV (Sigma), $0.5 \mathrm{mg} / \mathrm{ml}$ DNase (DNase I from a bovine pancreas; Sigma), and $2 \mathrm{mg} / \mathrm{ml}$ collagenase/dispase (Roche, Indianapolis, IN) before filtering through a $70-\mu \mathrm{m}$ cell strainer (BD Biosciences) (32). The resulting cell suspension was centrifuged at $1,400 \mathrm{rpm}$ for 5 minutes at $4^{\circ} \mathrm{C}$, and leukocytes were isolated by separation on a $40-70 \%$ percoll (GE Lifesciences, Piscataway, NJ) gradient (33). Isolated cells were incubated with FITC-anti-CD11b (BD Biosciences), phycoerythrin (PE)-labeled F4/80 (Invitrogen, Carlsbad, CA), or PE-labeled Gr1 (Ly-6G; BD Pharmingen, San Diego, California) antibodies for 30 minutes on ice, and 10,000 cells in each group were analyzed by FACS on a FACScan Flow cytometer (BD Biosciences).

\section{Primary Mouse Macrophages, Neutrophils, and Migration Assays}

Primary macrophages were harvested from the peritoneum (34) and primary neutrophils from the bone marrow (35) of mice. For the macrophage studies, a migration assay was performed as described previously $(35,36)$ using Biocoat Matrigel Invasion Chambers (BD Biosciences), a modified Boyden chamber assay, with upper and lower chambers separated by an $8-\mu \mathrm{m}$ microporous, polyethylene terephthalate membrane coated with a uniform layer of Matrigel Matrix, a prototype basement membrane. The lower chambers were filled with medium alone (RPMI 1,640 containing $10 \mathrm{mM}$ Hepes and $1 \%$ human serum albumin, $\mathrm{pH}$ 7.4) or medium containing mouse macrophage inflammatory protein (MIP)- $1 \alpha\left(10^{-9} \mathrm{M}\right)$, whereas macrophages $\left(3 \times 10^{6}\right.$ cells $)$ were placed in the upper chambers. The chambers were placed overnight in a humidified incubator set at $37^{\circ} \mathrm{C}$ with $5 \% \mathrm{CO}_{2}$, and macrophages that migrated through the membrane were stained with Hema 3 (Fisher Scientific, Pittsburgh, PA) and counted in 10 random, high-magnification fields $(\times 1,000)$. For the neutrophil studies, a traditional Boyden chamber assay was performed, with upper and lower chambers separated by an $8-\mu \mathrm{m}$ microporous membrane. The neutrophils $\left(4 \times 10^{6}\right.$ cells $)$ were placed in the upper chamber, and the lower chamber contained medium alone (as above) or medium plus keratinocyte-derived chemokine $\left(\mathrm{KC} ; 10^{-7} \mathrm{M}\right)$, a neutrophil chemoattractant. The chambers were incubated for 4 hours at $37^{\circ} \mathrm{C}$, and the neutrophils that migrated through the membrane were stained with Hema 3 and counted in 10 random, high-magnification fields $(\times 1,000)$.

\section{Western Blot Analyses}

Tissue was collected from mice receiving LPS or vehicle, and lysed in buffer containing $25 \mathrm{mM}$ Tris ( $\mathrm{pH} 7.5), 50 \mathrm{mM} \mathrm{NaCl}, 10 \mathrm{mM}$ EDTA, and complete protease inhibitors (Roche). Protein extracts were subjected to $15 \%$ SDS-PAGE, transferred to nitrocellulose membranes (Whatman, Inc., Florham Park, NJ), and then probed with a chicken anti-HMGB1 antibody (Shino-Test Corp.). After incubation with a peroxidase-conjugated secondary antibody, immunoreactive bands were visualized using an enhanced chemiluminescence kit (GE Lifesciences).

\section{Measurement of Plasma HMGB1 and HMGB1-Neutralizing Antibody Experiments}

HMGB1 protein in plasma was quantified by ELISA (Shino-Test Corp.) following the manufacturer's instructions. In $\mathrm{HO}-1^{-1-}$ mice, chicken anti-HMGB1 or control chicken IgY antibody $(200 \mu \mathrm{g} /$ mouse, intraperitoneally; Shino-Test Corp.) was administered 2 and 24 hours after the administration of LPS $(10 \mathrm{mg} / \mathrm{kg})$, and survival was then assessed.

\section{Statistical Analysis}

Data are expressed as mean $( \pm \mathrm{SEM})$. For comparisons between two groups, Student's two-tailed unpaired $t$ test was used. For comparison between more than two groups, and multiple comparisons, an ANOVA test was used. Comparisons of mortality were made by analyzing Kaplan-Meier survival curves, and then log-rank test was performed to assess for differences in survival. The number of samples per group $(n)$ is specified in the Results section or in the figure legends. Statistical significance is accepted at $P$ less than 0.05 . 


\section{RESULTS}

\section{HO-1 and Lung Inflammation}

To determine the role of HO-1 in lung inflammation, $\mathrm{HO}-1^{+/+}$ and $\mathrm{HO}-1^{-1-}$ mice were exposed to vehicle or LPS $(5 \mathrm{mg} / \mathrm{kg}$ intraperitoneally). Lungs of the mice were harvested 24 hours later, and processed for immunohistochemical staining using an antibody against a common leukocyte antigen, CD45. In the present study, baseline inflammation in the lungs of $\mathrm{HO}-1^{-1-}$ mice appeared increased (Figure 1A, representative image). Quantitation of CD45 staining revealed a 2-fold increase $(P<0.05)$ at baseline in $\mathrm{HO}-1^{-1-}(0.16 \pm 0.03 \% ; n=8)$ compared with $\mathrm{HO}-1^{+/+}(0.08 \pm 0.02 \% ; n=9)$ lungs. We have shown previously that, after LPS administration in the trachea, distal airway inflammatory cell accumulation, pulmonary edema, and alveolar destruction were not different between $\mathrm{HO}-1^{+/+}$and $\mathrm{HO}-1^{-/-}$mice (13). In the present study, CD45 staining was also not different in the lungs of $\mathrm{HO}-1^{+/+}$and HO- $1^{-1-}$ mice 24 hours after systemic LPS administration $(0.12 \pm 0.08 \%$ versus $0.11 \pm 0.04 \%$, respectively $)$. To further assess the composition of the inflammatory infiltrates in the interstitium of the lung (as airway inflammation is not prominent during endotoxemia), the lung tissue from $\mathrm{HO}-1^{+/+}$and $\mathrm{HO}-1^{-1-}$ mice exposed to vehicle or LPS were minced, digested, and leukocytes isolated (as described in MATERIALS AND Methods). The isolated cells were incubated with FITCanti-CD11b antibody and then PE-labeled anti-F4/80 or anti-Gr1 antibodies to assess macrophages and neutrophils, respectively, by FACs analysis. Figure $1 \mathrm{~B}$ shows a representative FACs analysis, and further quantitation was performed in three separate experiments. The fraction of macrophages $\left(\mathrm{F} 4 / 80^{+}\right.$ $\mathrm{CD} 11 \mathrm{~b}^{+}$) was increased in the lungs of $\mathrm{HO}-1^{-/-}$compared with $\mathrm{HO}-1^{+/+}$mice at baseline $(62 \pm 5 \%$ versus $29 \pm 5 \% ; n=3)$, and neutrophil $\left(\mathrm{Gr} 1^{+} \mathrm{CD} 11 \mathrm{~b}^{+}\right)$fraction was $67 \%( \pm 13 \%)$ versus $36 \%( \pm 2 \%)(n=3)$. The differences in cellular fractions in $\mathrm{HO}-1^{-1-}$ compared with $\mathrm{HO}-1^{+/+}$mice were not as pronounced for macrophages ( $76 \pm 3 \%$ versus $52 \pm 6 \% ; n=3$ ) and neutrophils ( $78 \pm 4 \%$ and $67 \pm 4 \% ; n=3$ ) after LPS administration.

\section{Migratory Potential of Primary Macrophages and Neutrophils in the Presence or Absence of HO-1}

Because the cells that are critical for the production and release of HMGB1 during an inflammatory response are monocytes and macrophages (17), we initially focused on macrophages in these assays. Macrophages harvested from HO- $1^{-1-}$ mice showed an increased ability to migrate in the absence of a chemokine gradient $(-\mathrm{MIP}-1 \alpha)$ compared with HO- $1^{+/+}$macrophages (Figure 2A). These data suggest the HO-1-deficient macrophages have the potential to migrate even in the absence of a chemokine gradient, which may help explain the increased presence of inflammatory cells in the lungs of $\mathrm{HO}-1^{-1-}$ mice at baseline. In the presence of the chemokine, MIP-1 $\alpha(+)$, directed migration was increased in both groups of macrophages (Figure 2A). Although the overall number of migrated cells was higher in the absence of $\mathrm{HO}-1$, the fold increase in migrated cells after MIP- $1 \alpha$ stimulation was greater in the $\mathrm{HO}-1^{+/+}$cells (5.5-fold) compared with $\mathrm{HO}-1^{-1-}$ cells $(2.3$-fold). These data correlate with the inflammatory response in vivo, as there were increased numbers of macrophages in $\mathrm{HO}-1^{-1-}$ lungs at baseline, but the macrophage response to LPS stimulation was greater in the lungs of $\mathrm{HO}-1^{+/+}$mice compared with $\mathrm{HO}-1^{-1-}$ mice. Analogous to the macrophage response, neutrophils harvested from $\mathrm{HO}-1^{-1-}$ mice showed an increased ability to
A
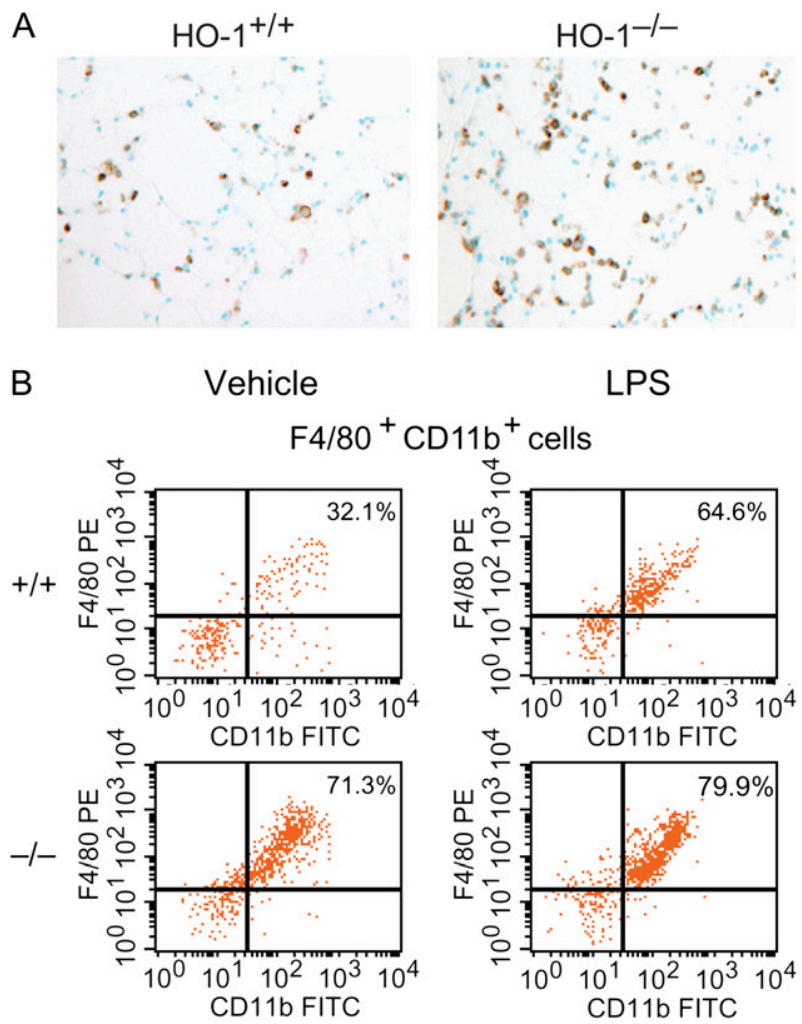

PS
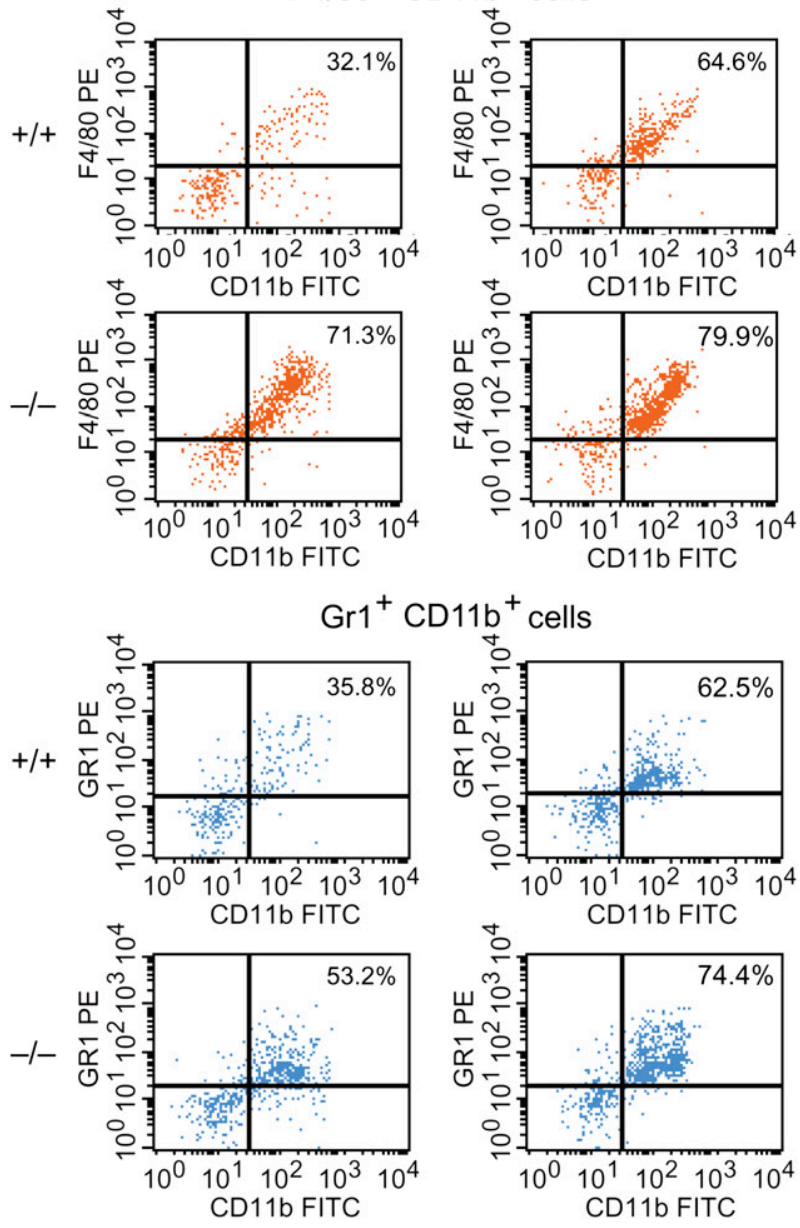

Figure 1. Increased inflammatory cells in the lungs of heme oxygenase (HO) $-1^{-/-}$compared with $\mathrm{HO}-1^{+/+}$mice. $(A)$ Lung tissue from $\mathrm{HO}-1^{+/+}$ and $\mathrm{HO}-1^{-1-}$ mice were immunostained with CD45 antibody. (B) After $\mathrm{HO}-1^{+/+}$and $\mathrm{HO}-1^{-/-}$mice were injected intraperitoneally with $5 \mathrm{mg} / \mathrm{kg}$ LPS for 24 hours, lung tissues were harvested, digested, and cells were isolated. FACS was performed by staining for markers of macrophages (F4/80, orange, upper panels) and neutrophils (Gr1, blue, lower panels) on CD11b-positive inflammatory cells. All experiments were performed a minimum of three independent times.

migrate in the absence of a chemokine gradient $(-\mathrm{KC}$; Figure 2B). In the presence of the chemokine, $\mathrm{KC}(+)$, directed migration was increased in both groups, but the fold increase was more robust in the $\mathrm{HO}-1^{+/}$cells $(2.1$-fold) compared with the HO- $1^{-1-}$ cells (1.5-fold). HO- $1^{+/-}$cells were used in the neutrophil migration assay, but we have shown previously that the response to an inflammatory stimulus is similar in $\mathrm{HO}-1^{+/-}$and $\mathrm{HO}-1^{+/+}$mice (13). 

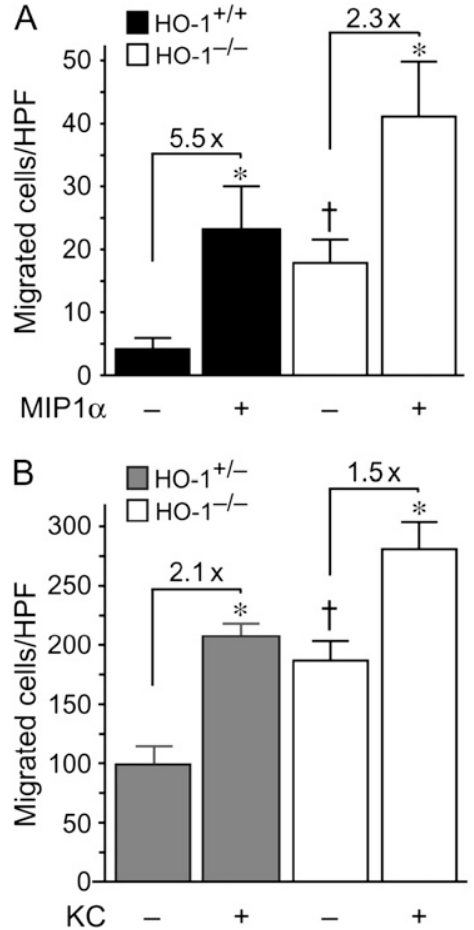

Figure 2. Increased migratory potential of $\mathrm{HO}-1^{-1-}$ inflammatory cells. (A) $\mathrm{HO}-1^{+/+}$ (closed bars) and $\mathrm{HO}-1^{-1-}$ (open bars) mouse macrophages were added to the upper compartments of Matrigel chambers, and the lower chambers contained vehicle $(-; n=12$ in each group) or macrophage inflammatory protein (MIP)-1 $\alpha\left(+; 10^{-9} \mathrm{M}\right.$; $n=7$ in each group). At 12 hours later, the cells in the upper chamber were removed by swabbing, the bottom of the membrane was stained, and cells that had migrated were counted in 10 random, high-power fields (HPF, $\times 1,000)$. ${ }^{*} P<0.05$ versus vehicle-treated $\mathrm{HO}^{+1 /+}(5.5-$ fold increase) and $\mathrm{HO}-1^{-1-}$ (2.3-fold increase) cells, respectively; ${ }^{\dagger} P<0.05$ versus vehicle-treated $\mathrm{HO}-1^{+/+}$cells. (B) $\mathrm{HO}-1^{+/-}$(gray bars) and $\mathrm{HO}-1^{-1-}$ (open bars) mouse neutrophils were added to the upper compartments of Boyden chambers; the lower chambers contained vehicle $\left(-; n=5\right.$ in each group) or $\mathrm{KC}\left(+; 10^{-7} \mathrm{M} ; n=5\right.$ in each group). At 4 hours later, the bottom of the membrane was stained, and cells that had migrated were counted in 10 random, high-power fields $(\mathrm{HPF} ; \times 1,000) .{ }^{*} P<0.05$ versus vehicle-treated $\mathrm{HO}-1^{+/-}(2.1$-fold increase) and $\mathrm{HO}-1^{-1-}\left(1.5\right.$-fold increase) cells, respectively; ${ }^{\dagger} p<0.05$ versus vehicle-treated $\mathrm{HO}-1^{+/-}$cells. Data are expressed as mean ( \pm SEM).

\section{Expression of HMGB1 in Tissue and Plasma of HO-1 ${ }^{-/-}$Mice}

Similar to the inflammatory response at baseline, there was evidence of increased HMGB1 immunostaining in the lungs of HO- $1^{-1-}$ mice (Figure $3 \mathrm{~A}$, representative images), and the immunostaining appeared to be predominantly in inflammatory cells. Quantitation of HMGB1 revealed an increased level of immunostaining $(P<0.05)$ at baseline in $\mathrm{HO}-1^{-1-}(1.10 \pm$ $0.004 \% ; n=6)$ compared with $\mathrm{HO}-1^{+/+}(0.26 \pm 0.09 \% ; n=8)$ lungs. Interestingly, in the absence of $\mathrm{HO}-1$, immunostaining for HMGB1 did not increase after the administration of LPS (Figure $3 \mathrm{~A})$ in $\mathrm{HO}-1^{-/-}(0.81 \pm 0.20 ; n=7)$ or $\mathrm{HO}-1^{+/+}(0.013 \pm$ $0.003 ; n=5)$ lungs. If anything, HMGB1 staining tended to decrease. This HMGB1 response was confirmed by Western blot analysis of lung tissue, which showed a higher level of HMGB1 at baseline in $\mathrm{HO}-1^{-/-}$compared with $\mathrm{HO}-1^{+/+}$tissue (Figure 3B). Moreover, in $\mathrm{HO}-1^{-1-}$ lungs, LPS administration did not cause an increase in HMGB1 protein expression. This absence of an increase in HMGB1 protein in $\mathrm{HO}-1^{-1-}$ mice after LPS was also evident in kidney tissue (Figure E1 in the online supplement), in which protein levels for HMGB1 decreased. Figure $3 \mathrm{C}$ emphasizes the point that expression of HMGB1 in primary macrophages is increased in $\mathrm{HO}-1^{-1-}$ cells compared with $\mathrm{HO}-1^{+/+}$cells.

Circulating levels of HMGB1 were also assessed in plasma of $\mathrm{HO}-1^{+/+}$and $\mathrm{HO}-1^{-1-}$ mice in the presence or absence of endotoxemia. Administration of a sublethal dose of $P$. aeruginosa LPS $(5 \mathrm{mg} / \mathrm{kg}$ for $24 \mathrm{~h})$ led to no increase in HMGB1 plasma levels in $\mathrm{HO}-1^{+/+}$mice, but a marked increase in HMGB1 in $\mathrm{HO}^{-1} 1^{-1-}$ mice (Figure 4). Next, CO-RM $(20 \mu \mathrm{M} / \mathrm{kg}$
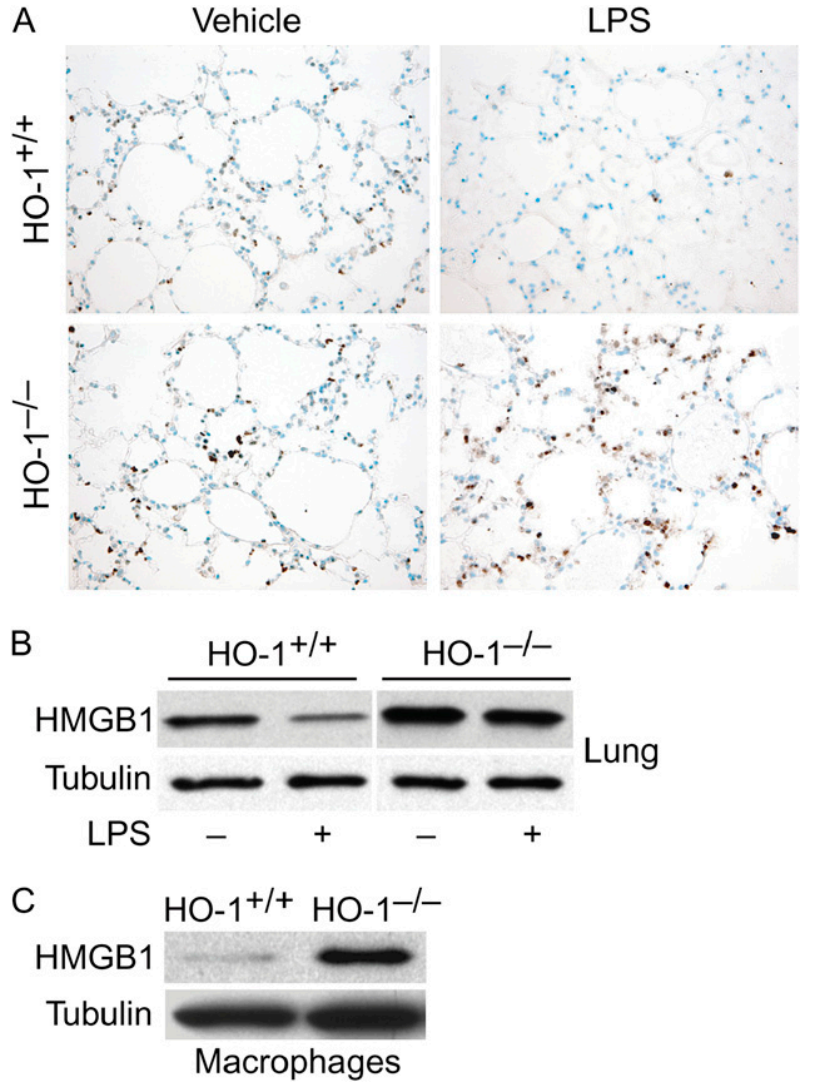

Figure 3. Tissue and cellular expression of high-mobility group box (HMGB)- 1 are increased in the lungs of $\mathrm{HO}-1^{-1-}$ mice. After $\mathrm{HO}-1^{+/+}$ and $\mathrm{HO}-1^{-1-}$ mice were injected with $5 \mathrm{mg} / \mathrm{kg}$ LPS for 24 hours, lung tissues were harvested. $(A)$ Immunostaining for HMGB1 in the lungs of $\mathrm{HO}-1^{+/+}$and $\mathrm{HO}-1^{-/-}$mice in the presence of vehicle or LPS. (B) Western blot analysis of HMGB1 protein expression in the lungs of $\mathrm{HO}-$ $1^{+/+}$and $\mathrm{HO}-1^{-/-}$mice after the intraperitoneal injection of vehicle (-) or LPS (+; $5 \mathrm{mg} / \mathrm{kg})$. (C) Western blot analysis of HMGB1 in primary macrophages harvested from $\mathrm{HO}-1^{+/+}$and $\mathrm{HO}-1^{-/-}$mice. In $(B)$ and $(C)$, the same membranes were blotted against tubulin to assess protein loading. All experiments were performed at a minimum of two independent times.

intraperitoneally) or biliverdin $(50 \mu \mathrm{M} / \mathrm{kg}$ intraperitoneally) was injected into $\mathrm{HO}-1^{-1-}$ mice at 24 hours and at 30 minutes before LPS administration (5 $\mathrm{mg} / \mathrm{kg}$ intraperitoneally), and plasma HMGB1 levels were assessed. Administration of CO$\mathrm{RM}$ or biliverdin to $\mathrm{HO}-1^{-/-}$mice was able to decrease the circulating levels of HMGB1 (Figure 4). Taken together, these data suggest that endogenous HMGB1 protein expression in tissue is not up-regulated by LPS, but that the increased numbers of inflammatory cells expressing greater amounts of HMGB1 at baseline release the protein during LPS exposure, leading to increased circulating levels in HO-1-deficient mice. The enhanced circulating levels of HMGB1 in $\mathrm{HO}-1^{-1-}$ mice can be blunted by treatment with CO-RM or biliverdin.

\section{Effects of CO-RM or Biliverdin, and Neutralizing Antibody to HMGB1, on the Outcome of HO-1 ${ }^{-/-}$Mice Exposed to Endotoxin}

We demonstrated that CO-RM and biliverdin were able to decrease the circulating levels of HMGB1 in $\mathrm{HO}-1^{-1-}$ mice during endotoxemia. Next, to determine whether CO-RM or biliverdin was able to rescue $\mathrm{HO}-1^{-1-}$ mice from the detrimental consequences of endotoxemia, mice were administered 


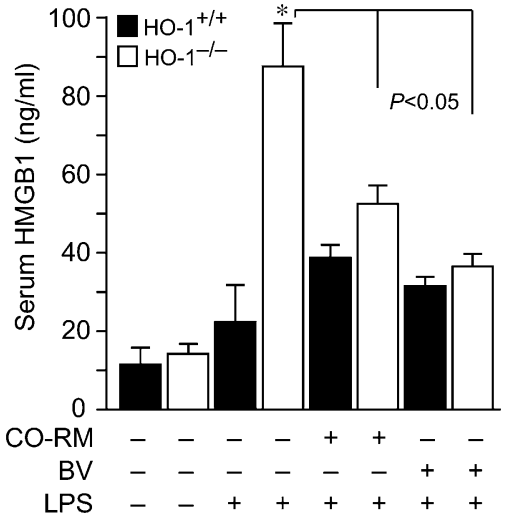

Figure 4. Reduction of endotoxin-induced circulating levels of HMGB1 by administration of carbon monoxide (CO)-releasing molecule (RM) or biliverdin to $\mathrm{HO}-1^{-1-}$ mice. Vehicle $(n=7)$ or LPS $(5 \mathrm{mg} / \mathrm{kg}$ intraperitoneally; $n=7$ ) was administered to $\mathrm{HO}-$ $1^{+/+}$and $\mathrm{HO}-1^{-/-}$mice. In a separate group of mice, CO-RM $(20 \mu \mathrm{M} / \mathrm{kg}$ intraperitoneally; $n=3$ ) or biliverdin $(50 \mu \mathrm{M} / \mathrm{kg}$ intraperitoneally; $n=3$ ) were injected at 24 hours and at 30 minutes before LPS administration ( $5 \mathrm{mg} / \mathrm{kg}$ intraperitoneally). At 24 hours after LPS exposure in each group, plasma levels of HMGB1 protein were quantified by ELISA. ${ }^{*} P<0.05$ versus vehicle- $(-)$ and LPS $(+)$-treated $\mathrm{HO}-1^{+/+}$and $\mathrm{HO}-1^{-/-}$mice. Data are expressed as mean ( \pm SEM).

a higher dose of LPS (10 mg/kg intraperitoneally), and lethality was assessed (Figure 5). CO-RM or biliverdin was also injected twice before LPS administration, with the dose of CO-RM and biliverdin being $20 \mu \mathrm{M} / \mathrm{kg}$ and $50 \mu \mathrm{M} / \mathrm{kg}$, respectively. Both CO-RM (Figure 5A, $P=0.008$ ) and biliverdin (Figure 5B, $P=$ $0.015)$ were able to dramatically improve survival of $\mathrm{HO}-1^{-1-}$ mice (by 57 and $50 \%$, respectively) after administration of LPS.

Finally, to determine whether HMGB1 may play a role in the detrimental outcome of endotoxemia in the absence of HO-1, we administered an HMGB1 neutralizing antibody to $\mathrm{HO}-1^{-1-}$ mice (200 $\mu \mathrm{g}$ intraperitoneally) 2 and 24 hours after the onset of endotoxemia (10 mg/kg LPS). Lethality was subsequently monitored over the next several days. Figure 6 reveals that administration of HMGB1-neutralizing antibody improved survival compared with control IgY antibody. Although the improvement in survival was not as dramatic as CO-RM or biliverdin replacement in $\mathrm{HO}-1^{-/-}$mice (given before LPS), the ability of HMGB1-neutralizing antibody to improve outcome after the onset of endotoxemia demonstrates that increased circulating HMGB1 contributes, in part, to the lethality of endotoxemia in the absence of endogenous HO-1.

\section{DISCUSSION}

HO-1 is an inducible, cytoprotective enzyme that breaks down the pro-oxidant heme to generate products, including $\mathrm{CO}$ and biliverdin/bilirubin (1-4). These products of heme catabolism have important endogenous anti-inflammatory and antioxidant properties, which help to maintain physiologic homeostasis. $\mathrm{CO}$ has been shown to inhibit LPS-induced production of proinflammatory cytokines (TNF- $\alpha$, IL-1 $\beta$, MIP-1 $\beta$, and IL-6), and increase production of the anti-inflammatory cytokine, IL-10 $(4,6$, 14). $\mathrm{CO}$ also has an inhibitory effect on granulocyte-macrophage colony-stimulating factor, which is known to promote the secretion of proinflammatory mediators $(4,37)$ and the differentiation of hematopoetic progenitor cells into macrophages and neutrophils (4). Administration of bilirubin was recently shown to blunt the inflammatory cascade in a model of rodent sepsis by decreasing IL-6 and monocyte chemoattractant protein-1, and increasing IL-10 (38). It has also been demonstrated that HO-1 and its products are able to modulate the expression of adhesion molecules, and leukocyte-endothelial interactions (39-42). In total, these studies imply that an absence of HO-1 promotes an inflammatory milieu. In the current study, we assessed the inflammatory response both at baseline and after LPS adminis-
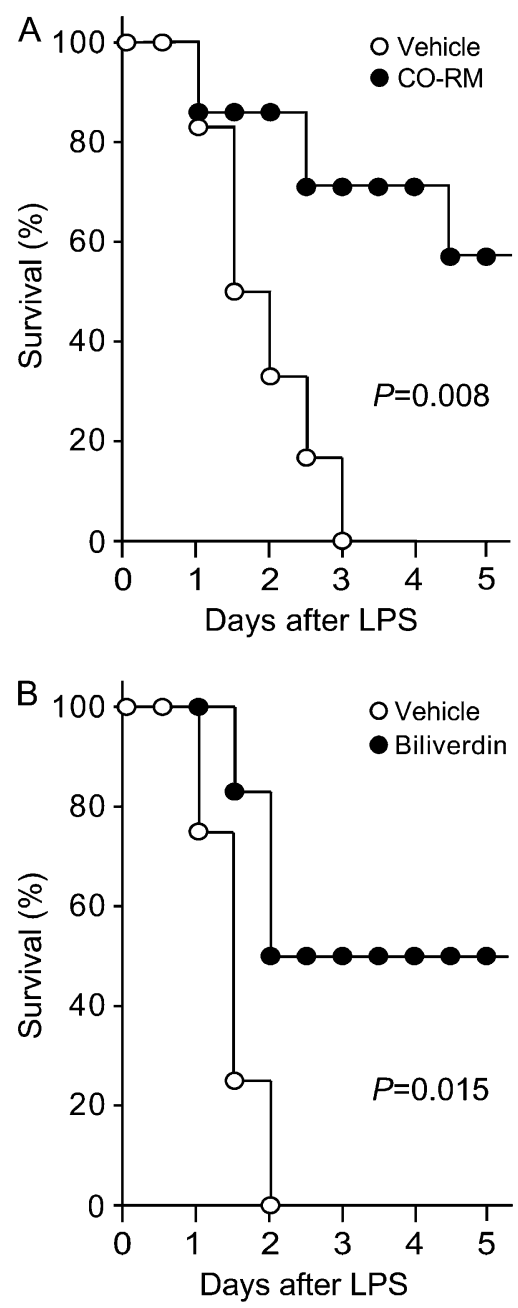

Figure 5. CO-RM and biliverdin rescue $\mathrm{HO}-1^{-1-}$ mice from the mortality of endotoxemia. $\mathrm{HO}-1^{-1-}$ mice were treated with either $(A)$ CO-RM $(n=7)$ or an equal volume of vehicle $(n=6)$, or $(B)$ biliverdin $(n=6)$ or an equal volume of vehicle $(n=4)$. CO-RM and biliverdin were also injected intraperitoneally twice before LPS administration (10 $\mathrm{mg} / \mathrm{kg}$ intraperitoneally), in a manner analogous to that in Figure 4, with the total dose of CO-RM and biliverdin being 20 and 50 $\mu \mathrm{M} / \mathrm{kg}$, respectively. Survival was assessed for 5 days after the LPS administration. $P=0.008(A)$ and $P=0.015(B)$.

tration in $\mathrm{HO}-1^{+/+}$and $\mathrm{HO}-1^{-/-}$mice. Interestingly, the predominant difference in inflammation between these groups of mice (more inflammatory cells in $\mathrm{HO}-1^{-1-}$ lungs) was evident at baseline, even more so than after LPS administration (Figure 1). In addition, total leukocytes and the percentage of macrophages and neutrophils at baseline were increased in lungs of $\mathrm{HO}-1^{-/-}$ mice. This suggests that HO-1 functions in the basal regulation of physiologic inflammation in the lung.

Although the mediation of cytokine and chemokine profiles by HO-1 and its metabolites has been studied extensively, to further explain the increased presence of inflammatory cells in the lungs of $\mathrm{HO}-1^{-1-}$ mice, we also sought to assess the migratory potential of macrophages and neutrophils in the presence and absence of HO-1. Migration of macrophages, in the absence of a chemokine gradient, was increased in $\mathrm{HO}-1^{-1-}$ compared with HO- $1^{+/+}$cells (Figure $2 \mathrm{~A}$ ). Chemokinesis was also increased in neutrophils of $\mathrm{HO}-1^{-1-}$ cells (Figure $2 \mathrm{~B}$ ). Other investigators have shown that adenoviral expression of HO-1 was critical for resolution of neutrophil migration into the lung after LPS (43). These data suggest that modulation of chemokinesis, in addition to chemotaxis, may contribute to the inflammatory response in HO-1-deficient mice.

Beyond the inflammatory response, oxidative stress is a critical component of the pathophysiologic response to systemic inflammatory diseases, such as endotoxemia and sepsis (44). In fact, we have shown previously that absence of HO-1 leads to increased oxidative stress, which contributes to end-organ injury and death in mice (13). Because it has recently been shown that release of HMGB1 is increased by oxidative stress in macro- 


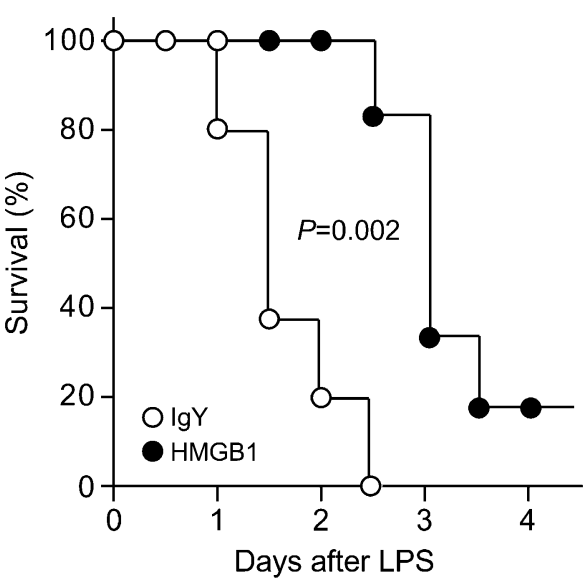

Figure 6. Neutralizing antibody to HMGB1 improves survival of HO$1^{-/-}$mice during endotoxemia. Control antibody (IgY; $200 \mu \mathrm{g} ; n=5$ ) or anti-HMGB1 $(200 \mu \mathrm{g} ; n=6)$ were administered intraperitoneally to HO- $1^{-1-}$ mice 2 and 24 hours after the onset of endotoxemia $(10 \mathrm{mg} / \mathrm{kg}$ LPS, intraperitoneally). Survival was assessed after the administration of LPS. $P=0.002$

phages and monocytes (45), we sought to determine whether absence of a molecule with antioxidant properties, HO-1, plays a role in the modulation of HMGB1 during systemic endotoxemia in vivo. When evaluating lung expression of HMGB1, levels were higher in $\mathrm{HO}-1^{-1-}$ mice compared with $\mathrm{HO}-1^{+/+}$ mice at baseline, and expression was localized to inflammatory cells, as confirmed in HO-1 $1^{-1-}$ macrophages (Figure 3). Investigators have shown previously that remarkably increased levels of HMGB1 occur in the serum of mice 16 hours after LPS administration, and levels remain elevated for more than 36 hours $(17,18)$. Whereas Hagiwara and colleagues (46) showed increased expression of HMGB1 in rat lungs 12 hours after intraperitoneal LPS administration, we did not find increased tissue expression of HMGB1 at a later time point $(24 \mathrm{~h})$ in either $\mathrm{HO}-1^{+/+}$or $\mathrm{HO}-1^{-1-}$ mice. Despite the lack of increased tissue expression by LPS in the present study (and a trend toward a decrease in lung and kidney expression [Figure 3B and Figure E1, respectively]), circulating levels of HMGB1 were higher in HO-1-null mice (Figure 4). This suggests a release of HMGB1 from inflammatory cells in HO-1 $1^{-1-}$ mice, which occurred at a low dose of LPS administration $(5 \mathrm{mg} /$ $\mathrm{kg}$ ) - a dose at which wild-type mice do not exhibit increased circulating levels of HMGB1 (Figure 4). Although this dose of LPS is not typically sufficient to cause death in wild-type mice, increased mortality occurs in HO-1-deficient mice (13).

A previous study investigated the effect of an inducer of HO-1, cobalt protoporphyrin (CoPP) IX, on expression of TNF$\alpha$ and HMGB1 during LPS-induced lung injury. This investigation showed less inflammation and tissue injury in mice receiving LPS pretreated with CoPPIX, in association with less HMGB1 mRNA and less protein in bronchoalveolar lavage fluid (47). However, the definitive role of HMGB1 in this CoPPIX response was not proven. In the present study, treatment with CO-RM or biliverdin was able to suppress the increased circulating levels of HMGB1 in $\mathrm{HO}-1^{-1-}$ mice (Figure 4), and even when a higher dose of LPS $(10 \mathrm{mg} / \mathrm{kg})$ was administered, replacement of CO-RM or biliverdin was able to significantly rescue $\mathrm{HO}-1^{-/-}$mice from the lethality of endotoxemia (Figure 5). To confirm that HMGB1 contributes to the pathobiology of endotoxemia in the absence of HO-1, a neutralizing antibody to HMGB1 was given to $\mathrm{HO}-1^{-1-}$ mice after the onset of endotoxemia. Treatment with anti-HMGB1 antibody compared with a control antibody was able to significantly improve survival in $\mathrm{HO}-1^{-1-}$ mice (Figure 6). Thus, the present study suggests that endogenous HO-1 is an important mediator of HMGB1 release in the setting of endotoxemia, and that the increased circulating levels of HMGB1 contribute to the enhanced lethality of endotoxemia in the absence of HO-1. These results may have interesting implications, particularly for patients with increased risk for inflammation and oxidative stress. Although the incidence of HO-1 deficiency in humans is rare, with one reported case (48), there has been increased appreciation of patients with polymorphisms of the HO-1 promoter leading to reduced expression of this cytoprotective enzyme $(28,49)$. The present study provides further insight into potential pathophysiologic mechanisms of disease when $\mathrm{HO}-1$ is deficient. Moreover, the present study provides additional supportive data in regard to the therapeutic potential of HO1 -derived heme metabolites in inflammatory disease processes.

Conflict of Interest Statement: None of the authors has a financial relationship with a commercial entity that has an interest in the subject of this manuscript.

Acknowledgments: The authors thank Bonna Ith for technical assistance, Cailin Harris for quantitation of the immunohistochemistry, Dr. Shingo Yamada for measurement of plasma HMGB1, Dr. Martin Knolle for assistance with migration assays, and Dr. S. Alex Mitsialis for help with $\mathrm{HO}-1^{-1-}$ mice. They also thank Dr. Matthew D. Layne for his help and suggestions regarding this study.

\section{References}

1. Choi AMK, Alam J. Heme oxygenase-1: function, regulation, and implication of a novel stress-inducible protein in oxidant-induced lung injury. Am J Respir Cell Mol Biol 1996;15:9-19.

2. Abraham NG, Kappas A. Heme oxygenase and the cardiovascular-renal system. Free Radic Biol Med 2005;39:1-25.

3. Maines MD, Gibbs PEM. 30 years of heme oxygenase: from a "molecular wrecking ball" to a "mesmerizing" trigger of cellular events. Biochem Biophys Res Commun 2005;338:568-577.

4. Ryter SW, Alam J, Choi AMK. Heme oxygenase-1/carbon monoxide: from basic science to therapeutic implications. Physiol Rev 2006;86:583-650.

5. Alam J, Cook JL. How many transcription factors does it take to turn on the heme oxygenase-1 gene? Am J Respir Cell Mol Biol 2007;36:166-174.

6. Ryter SW, Morse D, Choi AMK. Carbon monoxide and bilirubin: potential therapies for pulmonary/vascular injury and disease. $A m J$ Respir Cell Mol Biol 2007;36:175-182.

7. Stocker R, Yamamoto Y, McDonagh AF, Glazer AN, Ames BN. Bilirubin is an antioxidant of possible physiological importance. Science 1987;235:1043-1046.

8. Balla G, Jacob HS, Balla J, Rosenberg M, Nath K, Apple F, Eaton JW, Vercellotti GM. Ferritin: a cytoprotective antioxidant strategem of endothelium. J Biol Chem 1992;267:18148-18153.

9. Sarady-Andrews JK, Liu F, Gallo D, Nakao A, Overhaus M, Ollinger R, Choi AMK, Otterbein LE. Biliverdin administration protects against endotoxin-induced acute lung injury in rats. Am J Physiol Lung Cell Mol Physiol 2005;289:L1131-L1137.

10. Poss KD, Tonegawa S. Reduced stress defense in heme oxygenase 1deficient cells. Proc Natl Acad Sci USA 1997;94:10925-10930.

11. Poss KD, Tonegawa $\mathrm{S}$. Heme oxygenase 1 is required for mammalian iron reutilization. Proc Natl Acad Sci USA 1997;94:10919-10924.

12. Yet S-F, Perrella MA, Layne MD, Hsieh C-M, Maemura K, Kobzik L, Wiesel P, Christou H, Kourembanas S, Lee M-E. Hypoxia induces severe right ventricular dilatation and infarction in heme oxygenase-1 null mice. J Clin Invest 1999;103:R23-R29.

13. Wiesel P, Patel AP, DiFonzo N, Marria PB, Sim CU, Pellacani A, Maemura K, LeBlanc BW, Marino K, Doerschuk CM, et al. Endotoxin-induced mortality is related to increased oxidative stress and end-organ dysfunction, not refractory hypotension, in heme oxygenase-1 deficient mice. Circulation 2000;102:3015-3022.

14. Ryter SW, Otterbein LE, Morse D, Choi AMK. Heme oxygenase/ carbon monoxide signaling pathways: regulation and functional significance. Mol Cell Biochem 2002;234/235:249-263.

15. Kapturczak MH, Wasserfall C, Brusko T, Campbell-Thompson M, Ellis TM, Atkinson MA, Agarwal A. Heme oxygenase-1 modulates early inflammatory responses: evidence from the heme oxygenase-1deficient mouse. Am J Pathol 2004;165:1045-1053. 
16. Hesse DG, Tracey KJ, Fong Y, Manogue KR, Palladino MAJ, Cerami A, Shires GT, Lowry SF. Cytokine appearance in human endotoxemia and primate bacteremia. Surg Gynecol Obstet 1988;166:147153.

17. Wang H, Bloom O, Zhang M, Vishnubhakat JM, Ombrellino M, Che J, Frazier A, Yang H, Ivanova S, Borovikova L, et al. HMG-1 as a late mediator of endotoxin lethality in mice. Science 1999;285:248-251.

18. Wang H, Yang H, Czura CJ, Sama AE, Tracey KJ. HMGB1 as a late mediator of lethal systemic inflammation. Am J Respir Crit Care Med 2001;164:1768-1773.

19. Yang H, Ochani M, Li J, Qiang X, Tanovic M, Harris HE, Susarla SM, Ulloa L, Wang H, DiRaimo R, et al. Reversing established sepsis with antagonists of endogenous high-mobility groups box 1. Proc Natl Acad Sci USA 2004;101:296-301.

20. Suda K, Kitagawa Y, Ozawa S, Saikawa Y, Ueda M, Ebina M, Yamada S, Hashimoto S, Fukata S, Abraham E, et al. Anti-high-mobility group box chromosomal protein 1 antibodies improve survival of rats with sepsis. World J Surg 2006;30:1755-1762.

21. Matthay MA, Zimmerman GA, Esmon C, Bhattacharya J, Coller B, Doerschuk CM, Floros J, Gimbrone MAJ, Hoffman E, Hubmayr RD, et al. Future research directions in acute lung injury: summary of a National Heart, Lung, and Blood Institute working group. Am J Respir Crit Care Med 2003;167:1027-1035.

22. Abraham E, Arcaroli J, Carmody A, Wang H, Tracey KJ. HMG-1 as a mediator of acute lung inflammation. J Immunol 2000;165:29502954.

23. Liu G, Wang J, Park Y-J, Tsuruta Y, Lorne EF, Zhao X, Abraham E. High mobility group protein-1 inhibits phagocytosis of apoptotic neutrophils through binding to phosphatidylserine. J Immunol 2008;181:4240-4246.

24. Kim JY, Park JS, Strassheim D, Douglas I, Diaz del Valle F, Asehnoune K, Mitra S, Kwad SH, Yamada S, Maruyama I, et al. HMGB1 contributes to the development of acute lung injury after hemorrhage. Am J Physiol Lung Cell Mol Physiol 2005;288:L958-L965.

25. Rouhiainen A, Tumova S, Valmu L, Kalkkinen N, Vauvala H. Pivotal advance: analysis of proinflammatory activity of highly purified eukaryotic recombinant HMGB1 (amphoterin). J Leukoc Biol 2007;81:49-58.

26. Sha Y, Zmijewski J, Xu Z, Abraham E. HMGB1 develops enhanced proinflammatory activity by binding to cytokines. J Immunol 2008; 180:2531-2537.

27. Fredenburgh LE, Baron RM, Carvajal IM, Macias AA, Ith B, Perrella MA. Absence of heme oxygenase-1 expression in the lung parenchyma exacerbates endotoxin-induced acute lung injury and decreases surfactant protein-B levels. Cell Mol Biol 2005;51:513-520.

28. Fredenburgh LE, Perrella MA, Mitsialis SA. The role of heme oxygenase1 in pulmonary disease. Am J Respir Cell Mol Biol 2007;36:158-165.

29. Motterlini R, Clark JE, Foresti R, Sarathchandra P, Mann BE, Green CJ. Carbon monoxide-releasing molecules: characterization of biochemical and vascular activities. Circ Res 2002;90:e17-e24.

30. Yet S-F, Tian R, Layne M, Wang Z, Maemura K, Solovyeva M, Ith B, Melo L, Zhang L, Ingwall J, et al. Cardiac specific expression of heme oxygenase-1 protects against ischemia and reperfusion injury in transgenic mice. Circ Res 2001;89:168-173.

31. Yet S-F, Layne MD, Liu X, Chen Y-H, Ith B, Sibinga NES, Perrella MA. Absence of heme oxygenase-1 exacerbates atherosclerotic lesion formation and vascular remodeling. FASEB $J$ 2003;17:1759.

32. Arredouani MS, Franco F, Imrich A, Fedulov A, Lu X, Perkins D, Soininen R, Tryggvason K, Shapiro SD, Kobzik L. Scavenger receptors SR-AI/II and MARCO limit pulmonary dendritic cell migration and allergic airway inflammation. J Immunol 2007;178:5912-5920.

33. Cain JA, Deepe GS Jr. Evolution of the primary immune response to histoplasma capsulatum in murine lung. Infect Immun 1998;66:14731481.
34. Schreiber BM, Martin BM, Hollander W, Franzblau C. $\beta$-VLDL-induced alterations in growth potentiating activity produced by mononuclear phagocytes. Atherosclerosis 1988;69:69-79.

35. Owen CA, Hu Z, Barrick B, Shapiro SD. Inducible expression of tissue inhibitor of metalloproteinases-resistant matrix metalloproteinase-9 on the cell surface of neutrophils. Am J Respir Cell Mol Biol 2003;29: 283-294.

36. Owen CA, Hu Z, Lopez-Otin C, Shapiro SD. Membrane-bound matrix metalloproteinase- 8 on activated polymorphonuclear cells is a potent, tissue inhibitor of metalloproteinase-resistant collagenase and serpinase. J Immunol 2004;172:7791-7803.

37. Song R, Ning W, Lin F, Ameredes BT, Calhoun WJ, Otterbein LE, Choi AM. Regulation of IL-1 $\beta$-induced GM-CSF production in human airway smooth muscle cells by carbon monoxide. Am J Physiol Lung Cell Mol Physiol 2002;284:L50-L56.

38. Overhaus M, Moore BA, Barbato JE, Behrendt FF, Doering JG, Bauer AJ. Biliverdin protects against polymicrobial sepsis by modulating inflammatory mediators. Am J Physiol Gastrointest Liver Physiol 2006:290:G695-G703.

39. Hayashi S, Takamiya R, Yamaguchi T, Matsumoto K, Tojo SJ, Tamatani T, Kitajima M, Makino N, Ishimura Y, Suematsu M. Induction of heme oxygenase- 1 suppresses venular leukocyte adhesion elicited by oxidative stress: role of bilirubin generated by the enzyme. Circ Res 1999;85:663-671.

40. Soares MP, Seldon MP, Gregoire IP, Vassilevskaia T, Berberat PO, Yu J, Tsui T-Y, Bach FH. Heme oxygenase-1 modulates the expression of adhesion molecules associated with endothelial cell activation. J Immunol 2004;172:3553-3563.

41. Seldon MP, Silva G, Pejanovic N, Larsen R, Gregoire IP, Filipe J, Anrather J, Soares MP. Heme oxygenase-1 inhibits the expression of adhesion molecules associated with endothelial cell activation via inhibition of NF-кB RelA phosphorylation at serine 276. J Immunol 2007;179:7840-7851.

42. Urquhart P, Rosignoli G, Cooper D, Motterlini R, Perretti M. Carbon monoxide-releasing molecules modulate leukocyte-endothelial interactions under flow. J Pharmacol Exp Ther 2007;321:656-662.

43. Inoue S, Suzuki M, Nagashima Y, Suzuki S, Hashiba T, Tsuburai T, Ikehara K, Matsuse T, Ishigatsubo Y. Transfer of heme oxygenase 1 cDNA by a replication-deficient adenovirus enhances interleukin 10 production from alveolar macrophages that attenuates lipopolysaccharide-induced acute lung injury in mice. Hum Gene Ther 2001;12: 967-979.

44. Kolls JK. Oxidative stress in sepsis: a redox redux. J Clin Invest 2006;116: 860-863.

45. Tang D, Shi Y, Kang R, Li T, Xiao W, Wang H, Xiao X. Hydrogen peroxide stimulates macrophage and monocytes to actively release HMGB1. J Leukoc Biol 2007;81:741-747.

46. Hagiwara S, Iwasaka H, Togo K, Noguchi T. A neutrophil elastase inhibitor, Sivelestat, reduces lung injury following endotoxin-induced shock in rats by inhibiting HMGB1. Inflammation 2008;31:227-234.

47. Gong Q, Yin H, Fang M, Xiang Y, Yuan C-I, Zheng G-Y, Yang H, Xiong $\mathrm{P}$, Chen G, Gong F-I, et al. Heme oxygenase-1 upregulation significantly inhibits TNF- $\alpha$ and HMGB1 releasing and attenuates lipopolysaccharide-induced acute lung injury in mice. Int Immunopharmacol 2008;8:792-798

48. Yachie A, Niida Y, Wada T, Igarashi N, Kaneda H, Toma T, Ohta K, Kasahara Y, Koizumi S. Oxidative stress causes enhanced endothelial cell injury in human heme oxygenase-1 deficiency. J Clin Invest 1999; 103:129-135.

49. Exner M, Minar E, Wagner O, Schillinger M. The role of heme oxygenase-1 promoter polymorphisms in human disease. Free Radic Biol Med 2004:37:1097-1104. 